\title{
Hydrogen Selective Catalytic Reduction of Nitrogen Oxide on Pt- and Pd-based Catalysts for Lean-Burn Automobile Applications
}

\author{
Author, co-author (Do NOT enter this information. It will be pulled from participant tab in \\ MyTechZone) \\ Affiliation (Do NOT enter this information. It will be pulled from participant tab in MyTechZone)
}

\begin{abstract}
The utilization of $\mathrm{H}_{2}$ to catalytically treat $\mathrm{NO}$ emissions under leanburn engine exhaust conditions was studied on Pt- and Pd-containing catalysts supported on $\mathrm{CeO}_{2}$ and $\mathrm{MgO}$. The catalytic performance was examined using a fixed-bed reactor whose dry effluent gas stream was analyzed by an online FTIR analyzer. The catalysts NO conversion and $\mathrm{N}_{2}$ selectivity were measured in the range of $125-300^{\circ} \mathrm{C}$ with a feed gas composition of $0.05 \% \mathrm{NO} / 1 \% \mathrm{H}_{2} / 10 \% \mathrm{O}_{2} / \mathrm{N}_{2}$. The $\mathrm{CeO}_{2}$-based catalysts exhibited higher $\mathrm{NO}$ conversion, and the most effective catalyst was $\mathrm{Pd} / \mathrm{CeO}_{2}$, with a conversion of $67 \%$ and selectivity of $70 \%$ near $230^{\circ} \mathrm{C}$. The prepared solids were characterized using different techniques (BET, ICP-OES, CO pulse chemisorption, STEM, EELS and EDS) to correlate the structural and morphological properties of the metallic phase and the support with the catalytic activity. $\mathrm{CeO}_{2}$ is a more effective support as it yields higher metal dispersion and better facilitates the reduction of the Pt and Pd catalysts.
\end{abstract}

\section{Introduction}

Nearly one quarter of the global energy demand in 2017 was due to passenger cars [1]. The most consumed transportation fuel is motor gasoline with a share of $39 \%$, followed by diesel with a share of $36 \%$. Although motor gasoline and diesel shares are predicted to decline by 2040 , they are still expected to maintain shares of 33\% each and continue being the most dominant transportation fuel sources [2]. Of particular interest to this work is the control of NOx emissions that result from the combustion of gasoline and diesel in automobile applications. One method implemented in controlling NOx is the utilization of catalysts to accelerate and tailor the conversion of harmful NOx to harmless products.

In spark-ignition (SI) engines, the type of implemented emission control technology depends on the equivalence ratio $(\Phi)$, defined as the actual ratio of fuel to air to their stoichiometric ratio. For stoichiometric $(\Phi=1)$ and lean conditions $(\Phi<1)$, determination of efficiency can be achieved by examining the efficiency of an ideal Otto cycle, which is a set of processes in SI engines. At lean conditions, the air temperature of the combustion chamber is lower, and oxygen is more abundant as well. This increases the specific heat ratio and increases engine efficiency. However, despite the higher efficiency of lean combustion conditions, SI car engines are still run near stoichiometric conditions because the available emission control technology has been developed for these conditions. The technology that is by far most efficient in terms of reducing exhaust gas emissions in SI engines is the Three Way Catalyst (TWC) technology, where carbon monoxide $(\mathrm{CO})$, nitrogen oxide compounds $\left(\mathrm{NO}_{\mathrm{x}}\right)$ and

Page 1 of 9 unburned hydrocarbons (HC) are converted to carbon dioxide $\left(\mathrm{CO}_{2}\right)$, nitrogen $\left(\mathrm{N}_{2}\right)$ and water $\left(\mathrm{H}_{2} \mathrm{O}\right)$ at yields close to $100 \%$ near stoichiometric conditions [3]. However, the emission reduction landscape is different for lean-combustion SI engines, as technologies have not matured nearly as much as the TWC technology has. The oxidation of $\mathrm{CO}$ and $\mathrm{HC}$ is already achieved with TWC at lean-burn conditions, but the reduction of $\mathrm{NO}_{\mathrm{x}}$ remains a challenge.

The main two technologies available for lean-burn NOx aftertreatment in SI engines are $\mathrm{NO}_{\mathrm{x}}$ Storage Reduction (NSR), also commonly referred to as Lean $\mathrm{NO}_{\mathrm{x}}$ trap (LNT), and Selective Catalytic Reduction (SCR). In NSR, $\mathrm{NO}$ is oxidized to $\mathrm{NO}_{2}$ via a catalyst such as platinum, and the $\mathrm{NO}_{2}$ compounds are then trapped on a storage component, typically barium. As the storage component reaches saturation, the engine operation mode is switched to rich combustion conditions, where oxygen from the trapped $\mathrm{NO}_{2}$ is converted to $\mathrm{N}_{2}$ by the $\mathrm{HC}, \mathrm{H}_{2}$ and $\mathrm{CO}$ present in the exhaust gas. However, this technology faces issues with respect to catalyst selectivity, thermal stability and sulfur poisoning resistance [4]. The second promising technology is the Selective Catalytic Reduction (SCR). There are multiple types of SCR technologies, such as HC-SCR, CO-SCR, $\mathrm{NH}_{3}-$ SCR and $\mathrm{H}_{2}-\mathrm{SCR}$.

Unlike SI engines where there are different modes of operation, diesel engines universally run lean. While diesel engines typically have $30 \%$ better fuel economy in comparison to SI engines, their after-treatment is a challenge. The TWC technology cannot be used in diesel engines due to its ineffectiveness at lean-burn conditions. What is implemented instead are three technologies: Diesel Oxidation Catalyst (DOC), $\mathrm{NO}_{\mathrm{x}}$ Storage Reduction (NSR), and Selective Catalytic Reduction (SCR). With regards to the Diesel Oxidation Catalyst (DOC) technology, a catalyst is used to oxidize $\mathrm{CO}$ and unburned hydrocarbons to $\mathrm{CO}_{2}$ and $\mathrm{H}_{2} \mathrm{O}$. The concentration of oxygen in a diesel engine is sufficient to do the conversion, and typical levels of conversions at high temperatures $\left(>350^{\circ} \mathrm{C}\right)$ are over $90 \%$ [5]. This technology, however, is not concerned with reducing $\mathrm{NO}_{\mathrm{x}}$ emissions. Similar to the case in leanburn SI engines, $\mathrm{NO}_{\mathrm{x}}$ Storage Reduction (NSR) is used to reduce $\mathrm{NO}_{\mathrm{x}}$ compounds to $\mathrm{N}_{2}$. However, NSR faces the same aforementioned challenges in SI engines. Alternatively, SCR technology can be implemented using $\mathrm{NH}_{3}, \mathrm{H}_{2}$, $\mathrm{CO}$ or $\mathrm{HC}$.

Among the multiple technologies available for de- $\mathrm{NO}_{\mathrm{x}}$ operations in lean-burn conditions, $\mathrm{NH}_{3}-\mathrm{SCR}$ is commercially considered the most reliable method [6]. The relevant key reactions are:

$$
\begin{gathered}
4 \mathrm{NH}_{3}+4 \mathrm{NO}+\mathrm{O}_{2} \rightarrow 4 \mathrm{~N}_{2}+6 \mathrm{H}_{2} \mathrm{O} \\
4 \mathrm{NH}_{3}+2 \mathrm{NO}+2 \mathrm{NO}_{2} \rightarrow 4 \mathrm{~N}_{2}+6 \mathrm{H}_{2} \mathrm{O}
\end{gathered}
$$


Ammonia in the presence of oxygen converts $\mathrm{NO}_{x}$ compounds to $\mathrm{N}_{2}$ and $\mathrm{H}_{2} \mathrm{O}$, as indicated in reaction (1). In diesel engine applications, the after-treatment reactions take place downstream of diesel oxidation catalysts, where $\mathrm{NO}$ is oxidized to $\mathrm{NO}_{2}$. In such conditions, reaction (2) is much faster and, therefore, more relevant [6]. In automotive applications, $\mathrm{NH}_{3}$ is not directly used; instead, urea is injected as a fluid which, upon exposure to heat, decomposes to $\mathrm{NH}_{3}$ and $\mathrm{CO}_{2}$.

While $\mathrm{NH}_{3}$-SCR has proven successful as an effective means to address the recent stringent regulations, there remain challenges such as ammonia slip, air-heater fouling, and high operating costs [7]. These challenges demand more innovative, sustainable technologies that are carbon-free, especially as regulations are expected to only become more stringent. This is where $\mathrm{H}_{2}-\mathrm{SCR}$ presents itself as a promising alternative technology.

The hydrogen selective catalytic reduction of $\mathrm{NO}_{\mathrm{x}}$ components $\left(\mathrm{H}_{2}-\right.$ SCR) proceeds according to the following three reactions

$$
\begin{aligned}
2 \mathrm{NO}+4 \mathrm{H}_{2}+\mathrm{O}_{2} & \rightarrow \mathrm{N}_{2}+4 \mathrm{H}_{2} \mathrm{O} \\
2 \mathrm{NO}+3 \mathrm{H}_{2}+\mathrm{O}_{2} & \rightarrow \mathrm{N}_{2} \mathrm{O}+3 \mathrm{H}_{2} \mathrm{O} \\
\mathrm{O}_{2}+2 \mathrm{H}_{2} & \rightarrow 2 \mathrm{H}_{2} \mathrm{O}
\end{aligned}
$$

When achieving high selectivity towards $\mathrm{N}_{2}, \mathrm{H}_{2}-\mathrm{SCR}$ is environmentally benign as the combustion of hydrogen only produces water. Since reactions (4) and (5) are undesirable, researchers have focused on developing catalysts that are highly selective towards reaction (3), resulting in $\mathrm{N}_{2}$ and $\mathrm{H}_{2} \mathrm{O}$ [6]. Table 1 is a literature survey of some of the most successful $\mathrm{H}_{2}$-SCR attempts for automotive applications. While high conversion levels of $\mathrm{NO}$ have been achieved, the selectivity towards $\mathrm{N}_{2}$ remains a challenge.

The objective of this work is to investigate effective platinum- and palladium-based catalysts, namely 1 wt. $\% \mathrm{Pt} / \mathrm{CeO}_{2}, \mathrm{Pd} / \mathrm{CeO}_{2}, \mathrm{Pt} / \mathrm{MgO}$ and $\mathrm{Pd} / \mathrm{MgO}$, for the lean-burn hydrogen selective catalytic reduction of NO in automotive applications. Both spark and compression ignition engines are targeted. In addition, this work is concerned with characterizing these catalysts for a better understanding of the activity and selectivity results.

It is important to note that the present study is focused on operation conditions with respect to the oxygen content downstream of lean-burn engines. Specifically, compared to the referenced studies in Table 1, the feed stream in the current study includes at least twice as much oxygen and, in some cases, less hydrogen content. The increased oxygen content promotes reaction (5) to take place, negatively influencing the rate of reaction (3), where $\mathrm{N}_{2}$ is produced.

Lastly, the current study is conducted under dry conditions, i.e. without the presence of water in the feed. The presence of water can have serious detrimental effects on $\mathrm{H}_{2}-\mathrm{SCR}$. Liu et al. [8] reported that the presence of $\mathrm{H}_{2} \mathrm{O}$ decreased the $\mathrm{NO}_{\mathrm{x}}$ conversion on a Pt-based catalyst by up to $100 \%$, and they attributed the decrease to competitive adsorption between $\mathrm{H}_{2} \mathrm{O}$ and the reactants. However, the presence of $\mathrm{H}_{2} \mathrm{O}$ can lead to positive effects. Xu et al. [9] reported that an increase in NO conversion was observed on a Pd-based catalyst when adding $5 \% \mathrm{H}_{2} \mathrm{O}$. The authors attributed the positive effect to the dissociation of $\mathrm{H}_{2} \mathrm{O}$, which formed adsorbed $\mathrm{H}$ species that turned $\mathrm{NO}$ to $\mathrm{N}$ and further increased NO conversion [9]. The current study is a first step into investigating a highly $\mathrm{O}_{2}$-rich feed, and subsequent steps will include investigating the effects of adding $\mathrm{H}_{2} \mathrm{O}, \mathrm{CO}, \mathrm{CO}_{2}$ and $\mathrm{SO}_{2}$ to the feed.

\section{Methodology}

\section{Catalyst Preparation}

Cerium oxide $\left(\mathrm{CeO}_{2}\right)$ and magnesium oxide $(\mathrm{MgO})$ were used as supports. The catalysts 1 wt. $\% \mathrm{Pt} / \mathrm{CeO}_{2}, \mathrm{Pd} / \mathrm{CeO}_{2}, \mathrm{Pt} / \mathrm{MgO}$ and $\mathrm{Pd} / \mathrm{MgO}$ were prepared using the widely applied wetness impregnation method. $\mathrm{H}_{2} \mathrm{PtCl}_{6} \cdot 6 \mathrm{H}_{2} \mathrm{O}$ and $\mathrm{Pd}\left(\mathrm{NO}_{3}\right)_{2}$ were used as precursors of $\mathrm{Pt}$ and $\mathrm{Pd}$, respectively. The metal oxide support $(5 \mathrm{~g})$ was mixed in a rotary evaporator with $150 \mathrm{~mL}$ of deionized water, then a given amount

\begin{tabular}{|c|c|c|c|c|c|c|}
\hline & $\begin{array}{c}\text { Liu et al. } \\
{[8]}\end{array}$ & $\begin{array}{c}\text { Xu et al. } \\
{[9]}\end{array}$ & $\begin{array}{c}\text { Duan et al. } \\
{[10]}\end{array}$ & $\begin{array}{c}\text { Li et al. } \\
{[11]}\end{array}$ & $\begin{array}{c}\text { Costa et al. } \\
{[12]}\end{array}$ & $\begin{array}{c}\text { Costa et al. } \\
{[13]}\end{array}$ \\
\hline Catalyst & $\mathrm{Pt} / \mathrm{TiO}_{2}$ with $\mathrm{WO}_{3}$ & Co-AlPd & $\mathrm{Pd}-\mathrm{Au} / \mathrm{TiO}_{2}$ & $\mathrm{Pd}-\mathrm{Ir} / \mathrm{Ti}_{2} \mathrm{O}$ & $\mathrm{Pt} / \mathrm{MgO}-\mathrm{CeO}_{2}$ & $\mathrm{Pt} / \mathrm{Mg}-\mathrm{Ce}-\mathrm{O}$ \\
\hline Catalyst Loading & $2 \% \mathrm{Pt}$ & - & $\begin{array}{l}1 \% \mathrm{Pd} \\
0.5 \% \mathrm{Au}\end{array}$ & $\begin{array}{c}0.9 \% \mathrm{Pd}, \\
0.8 \% \mathrm{Ir}\end{array}$ & $0.1 \% \mathrm{Pt}$ & $0.1 \% \mathrm{Pt}$ \\
\hline Temperature $\left({ }^{\circ} \mathrm{C}\right)$ & $100-175$ & $230-250$ & $100-400$ & $140-200$ & $100-150$ & $100-400$ \\
\hline GHSV $\left(\mathbf{h r} \mathbf{r}^{-1}\right)$ & 53,000 & 23,400 & 50,000 & 60,000 & 40,000 & 80,000 \\
\hline Feed flowrate $(\mathrm{mL} / \mathrm{min})$ & 200 & - & 200 & 100 & 100 & 100 \\
\hline $\mathrm{H}_{2}$ feed $(\%)$ & 1 & 1 & 1 & 0.3 & 1.5 & 1 \\
\hline NO feed (\%) & 0.25 & 0.1 & 0.25 & 0.1 & 0.1 & 0.25 \\
\hline $\mathrm{O}_{2}$ feed $(\%)$ & 5 & 2 & 5 & 5 & 5 & 5 \\
\hline $\mathrm{H}_{2} \mathrm{O}$ feed $(\%)$ & 5 & NA & NA & NA & 5 & 10 \\
\hline CO feed (\%) & 0.01 & NA & NA & NA & $0-0.5$ & NA \\
\hline $\mathrm{CO}_{2}$ feed $(\%)$ & NA & NA & NA & NA & 10 & NA \\
\hline Balance Gas & Helium & Nitrogen & Helium & Helium & Helium & Helium \\
\hline NO conversion (\%) & 88 & 95 & $>70$ & $>80$ & 100 & 95 \\
\hline $\mathrm{N}_{2}$ Selectivity (\%) & 78 & - & $>70$ & $>80$ & 85 & 85 \\
\hline Year & 2016 & 2016 & 2014 & 2012 & 2007 & 2004 \\
\hline
\end{tabular}
of the Pt or Pd precursor corresponding to $1 \%$ loading was added. After

Table 1. Literature survey of $\mathrm{H}_{2}$-SCR for automotive applications

Page 2 of 9 
gradual evaporation of water at $70^{\circ} \mathrm{C}$ for 4 hours in the rotary evaporator (200mbar, 200rpm), the resulting slurry was dried overnight at $120^{\circ} \mathrm{C}$, then it was calcined at $600^{\circ} \mathrm{C}$ for two hours in a furnace under static air with a heating rate of $5^{\circ} \mathrm{C} / \mathrm{min}$. The $\mathrm{Pt}$ and $\mathrm{Pd}$ catalysts were subsequently loaded to the reactor.

\section{Catalyst characterization}

Both supports were physically characterized by nitrogen adsorption at $77 \mathrm{~K}$ on an ASAP 2020. The surface area was estimated by the BET method in a relative pressure range of $0.05-0.3$. The support pore size was determined at a relative pressure of 0.98 . To estimate the amount of metal on the support, and thus determine the composition of the catalyst, Inductively Coupled Plasma Optical Emission Spectroscopy (ICP-OES) was employed. The experiments were held in 5110 ICPOES made by Agilent Technologies. Prior to ICP-OES, the samples were digested in an ETHOS 1 closed vessel microwave digestion instrument. Around $0.5 \mathrm{~g}$ of each sample and $8 \mathrm{~mL}$ of aqua regia (a mixture of nitric acid and hydrochloric acid with a 1:3 molar ratio) were loaded into Polytetrafluoroethylene (PTFE) vessels. The samples were digested at $220^{\circ} \mathrm{C}$ for 20 minutes. After cooling to room temperature, the samples were diluted in deionized water and then tested.

To determine the reducibility of the catalysts, $\mathrm{H}_{2}$-temperature programmed reduction $\left(\mathrm{H}_{2}\right.$ - TPR) experiments were performed in a fully automated chemisorption analyzer, AutoChem II 2920. About $300 \mathrm{mg}$ of the sample was packed into a quartz reactor and purged by high purity helium at $50 \mathrm{~mL} \mathrm{~min}{ }^{-1}$ and $150^{\circ} \mathrm{C}$ for one hour, then the sample was cooled to room temperature. After purging, the sample was heated to $500^{\circ} \mathrm{C}$ at $10^{\circ} \mathrm{C} \mathrm{m^{-1 }}$ under $10 \% \mathrm{H}_{2} / \mathrm{Ar}$ flow. A thermal conductivity detector (TCD) was used to monitor the consumption of hydrogen.

To determine the metal dispersion, $\mathrm{CO}$ pulse chemisorption experiments were conducted in an AutoChem $2950 \mathrm{HP}$ analyzer. Around $300 \mathrm{mg}$ of each catalyst was loaded into a U-quartz reactor. The samples were purged by flowing high purity helium at $50 \mathrm{~mL}$ $\mathrm{min}^{-1}$ at $150^{\circ} \mathrm{C}$ for one hour. The purging was followed by a reduction step where the catalyst was heated to the reduction temperature obtained by $\mathrm{H}_{2}$-TPR experiments. The heating rate was $10^{\circ} \mathrm{C}$ min $^{-1}$ and reduction was conducted under $50 \mathrm{~mL} \mathrm{~min}^{-1}$ of $10 \% \mathrm{H}_{2} / \mathrm{Ar}$. The sample was held at the reduction temperature for 60 minutes to ensure the total reduction of the catalyst. The sample was then cooled to $35^{\circ} \mathrm{C}$ and pulsed with carbon monoxide until the surface was totally covered by chemisorbed $\mathrm{CO}$. The evolution of the test was detected by a TCD, and the CO-metal stoichiometry was assumed to be $1: 1$ for Pt [14] and 1:2 for Pd [15].

To examine the catalyst morphology and quantify the particle size distribution, the samples were analyzed using a double sphericalaberration corrected transmission electron microscope (TEM) Titan ThemisZ (Thermo-Fisher Scientific). The analysis was performed by operating the microscope at an accelerating voltage of $300 \mathrm{kV}$. The TEM-specimens were prepared by drop-casting a small amount of sample-and-water solution $(\sim 2 \mu \mathrm{L})$ onto holey-carbon coated copper grids. The solution-containing grids were quickly blotted then air-dried for several hours before their TEM-analysis was performed. Brightfield TEM (BF-TEM) images were recorded with a $4 \mathrm{k} \times 4 \mathrm{k}$ complementary metal oxide semiconductor (CMOS) camera of Ceta (Thermo-Fisher Scientific) that was installed beneath the projection chamber of the microscope. During the BF-TEM imaging of samples, the corresponding X-ray energy-dispersive spectroscopy (EDS) spectra were also acquired to confirm the presence of elements in each synthesized sample. Furthermore, the microscope was also equipped

Page 3 of 9 with a high-angle annular dark-field (HAADF) detector to record atomic number $(\mathrm{Z})$ sensitive dark-field scanning TEM (DF-STEM) images. Moreover, DF-STEM imaging analysis was combined with simultaneous EDS acquisitions to generate spectrum-imaging (SI) datasets to generate elemental maps of elements present in the samples. The data acquisition as well as proceeding analysis was performed in Velox Package of version 2.6x.

\section{Experimental Setup}

The experiment was conducted in a steel fixed-bed reactor, where the catalyst was loaded. A schematic diagram of the reactor is shown in the appendix. The inside and outside diameters are $17.5 \mathrm{~mm}$ and 25.4 $\mathrm{mm}$, respectively. Feeding into the reactor were three lines: $25 \%$ $\mathrm{H}_{2} / \mathrm{N}_{2}, 0.1 \% \mathrm{NO} / 2 \% \mathrm{H}_{2} / \mathrm{N}_{2}$, and $20 \% \mathrm{O}_{2} / \mathrm{N}_{2}$ lines. The reactor was surrounded by a heater for temperature control.

Additionally, available was a pure $\mathrm{N}_{2}$ supply, which was used for purging the setup and daily-zeroing the $\mathrm{NO}_{\mathrm{x}}$ analyzer downstream of the reactor. Upon exiting the reactor, the outlet was cooled down to condense $\mathrm{H}_{2} \mathrm{O}$, and the remaining gases went through an online Fourier-Transform Infrared Spectroscopy (FTIR) $\mathrm{NO}_{\mathrm{x}}$ analyzer model MIR 9000 by Environnement S.A. From the analyzer output, $\mathrm{NO}$ conversion and $\mathrm{N}_{2}$ selectivity were calculated based on the formulas below. Quantities of $\mathrm{NH}_{3}$ as a result of over reducing $\mathrm{NO}$ were expected to be small, so $\mathrm{NH}_{3}$ was not measured at the exit of the rector.

$$
\begin{aligned}
& \mathrm{NO} \text { conversion }=\frac{\mathrm{ppm} \text { of } \mathrm{NO} \text { in }-\mathrm{ppm} \text { of } \mathrm{NO} \text { out }}{\mathrm{ppm} \text { of } \mathrm{NO} \text { in }} \times 100 \% \\
& \mathrm{~N}_{2} \text { selectivity }=100 \%-\mathrm{N}_{2} \mathrm{O} \text { selectivity }-\mathrm{NO}_{2} \text { selectivity } \\
& \mathrm{N}_{2} \mathrm{O} \text { selectivity }=\frac{2 \times \text { ppm of } \mathrm{N}_{2} \mathrm{O} \text { out }}{\text { ppm of NO in }- \text { ppm of NO out }} \times 100 \% \\
& \mathrm{NO}_{2} \text { selectivity }=\frac{\text { ppm of } \mathrm{NO}_{2} \text { out }}{\text { ppm of } \mathrm{NO} \text { in }-\mathrm{ppm} \text { of } \mathrm{NO} \text { out }} \times 100 \%
\end{aligned}
$$

\section{Testing Procedure and Reaction Conditions}

First, the oxidized catalyst was reduced in the reactor by flowing $\mathrm{H}_{2}$ at $250^{\circ} \mathrm{C}$, the setup was purged with $\mathrm{N}_{2}$, and the reactor was cooled down to $125^{\circ} \mathrm{C}$. The reactor was bypassed, the reaction mixture was fed to the NOx analyzer before a reaction took place, and the feed measurement was recorded. Then the feed was sent through the reactor where the SCR reaction took place, and measurements were recorded in increments of $25^{\circ} \mathrm{C}$ from $125^{\circ} \mathrm{C}$ to $300^{\circ} \mathrm{C}$. The same steady-state testing procedure was applied to the $\mathrm{CeO}_{2}$ and $\mathrm{MgO}$ supports alone to determine the catalytic activity of the support without the metal.

Throughout the experiment, the pressure was ambient and the gas hourly space velocity (GHSV) was maintained at 50,000 $\mathrm{hr}^{-1}$. During the reaction steps, feeding into the reactor were $50 \mathrm{NL} / \mathrm{hr} \mathrm{NO} / \mathrm{H}_{2} / \mathrm{N}_{2}$ and $50 \mathrm{NL} / \mathrm{hr} \mathrm{O}_{2} / \mathrm{N}_{2}$. This made the feed composition as follows: 500 ppm NO, $1 \% \mathrm{H}_{2}, 10 \% \mathrm{O}_{2}$, with $\mathrm{N}_{2}$ as the balance gas.

\section{Results and Discussion}

\section{Catalyst Characterization}

The BET results are shown in Table 2; the BET surface area of $\mathrm{MgO}$ was much higher than that of $\mathrm{CeO}_{2}$. The adsorption isotherms are included in the appendix. ICP results, shown in Table 3, confirm that the actual metal amounts in the samples were close to $1 \mathrm{wt} \%$. Additionally, $\mathrm{CO}$ pulse chemisorption shows that the dispersion values for $\mathrm{CeO}_{2}$ supported catalysts were virtually the same. The active particle diameter values of the $\mathrm{CeO}_{2}$ catalysts were similar, too, and 
the similarity was indeed observed via electron microscopy as well. No similarity was observed among the $\mathrm{MgO}$ catalysts, as their dispersion values greatly differed.

Table 2. BET surface area and pose size results for the supports $\mathrm{CeO}_{2}$ and $\mathrm{MgO}$

\begin{tabular}{c|cc} 
& $\begin{array}{c}\text { Surface area } \\
\left(\mathbf{m}^{2} / \mathbf{g}\right)\end{array}$ & $\begin{array}{c}\text { Pore size } \\
(\mathbf{n m})\end{array}$ \\
\hline $\mathbf{C e O}_{2}$ & 3 & 24 \\
$\mathbf{M g O}$ & 38 & 19
\end{tabular}

Table 3. Summary of ICP and CO pulse chemisorption experiments for 1 wt. \% $\mathrm{Pt} / \mathrm{CeO} 2, \mathrm{Pd} / \mathrm{CeO}_{2}, \mathrm{Pt} / \mathrm{MgO}$, and $\mathrm{Pd} / \mathrm{MgO}$

\begin{tabular}{l|ccc} 
& & \multicolumn{2}{c}{ CO pulse chemisorption } \\
\cline { 3 - 4 } & $\begin{array}{c}\text { ICP metal } \\
\text { content (\%) }\end{array}$ & $\begin{array}{c}\text { Dispersion } \\
(\%)\end{array}$ & $\begin{array}{c}\text { Active particle } \\
\text { diameter (nm) }\end{array}$ \\
\hline $\mathbf{P t} / \mathbf{C e O}_{2}$ & $0.7 \%$ & $21 \%$ & 5 \\
$\mathbf{P d} / \mathbf{C e O}_{2}$ & $1.0 \%$ & $19 \%$ & 6 \\
$\mathbf{P t / M g O}$ & $0.7 \%$ & $7 \%$ & 16 \\
$\mathbf{P d} / \mathbf{M g O}$ & $0.9 \%$ & $25 \%$ & 4
\end{tabular}

The Hydrogen Temperature-Programmed Reduction $\left(\mathrm{H}_{2}-\mathrm{TPR}\right)$ results for $\mathrm{Pt} / \mathrm{CeO}_{2}, \mathrm{Pd} / \mathrm{CeO}_{2}, \mathrm{Pt} / \mathrm{MgO}$, and $\mathrm{Pd} / \mathrm{MgO}$ are shown in Fig. 1. The TPR plots of the supports $\mathrm{CeO}_{2}$ and $\mathrm{MgO}$ are also shown. For $\mathrm{MgO}$, no reduction behavior was detected by the TCD within the temperature range. The same behavior was observed for $\mathrm{CeO}_{2}$, though a minor peak was observed near $480^{\circ} \mathrm{C}$, which is attributed to the reduction of oxygen on the surface of $\mathrm{CeO}_{2}$, as has been reported in previous studies [16]. On $\mathrm{CeO}_{2}$, Pt exhibited two peaks: one near $80^{\circ} \mathrm{C}$ owing to the platinum metal and one near $300^{\circ} \mathrm{C}$ due to ceria oxygen [16]. $\mathrm{Pd} / \mathrm{CeO}_{2}$ exhibited one peak near $80^{\circ} \mathrm{C}$ owing to various Pd states [17]. On MgO, Pt exhibited two peaks in the $300-450^{\circ} \mathrm{C}$ temperature range. Similar behavior was previously reported by other authors, where it was attributed to the reduction of $\mathrm{Pt}^{4+}$ to $\mathrm{Pt}^{2+}[18]$. $\mathrm{Pd} / \mathrm{MgO}$ showed a minor peak near $90^{\circ} \mathrm{C}$ and a wide peak near $450^{\circ} \mathrm{C}$, which is similar to previous work [19], in which the $90^{\circ} \mathrm{C}$ peak was attributed to either the $\mathrm{Pd}$ metal, the chemisorption of $\mathrm{H}_{2}$ on $\mathrm{Pd}$, or the adsorption of $\mathrm{H}_{2}$ on the $\mathrm{MgO}$ surface as well as spillover species, and the $450^{\circ} \mathrm{C}$ peak was attributed to further hydrogen consumption occurring potentially on the $\mathrm{MgO}$ support. Lastly, the differing $\mathrm{H}_{2}$-TPR behaviors of $\mathrm{Pt}$ and $\mathrm{Pd}$ on $\mathrm{MgO}$ show a stronger metal-support interaction between $\mathrm{Pt}$ and $\mathrm{MgO}$. This can explain the difference in dispersion, and therefore particle size, between Pt and Pd on $\mathrm{MgO}$.

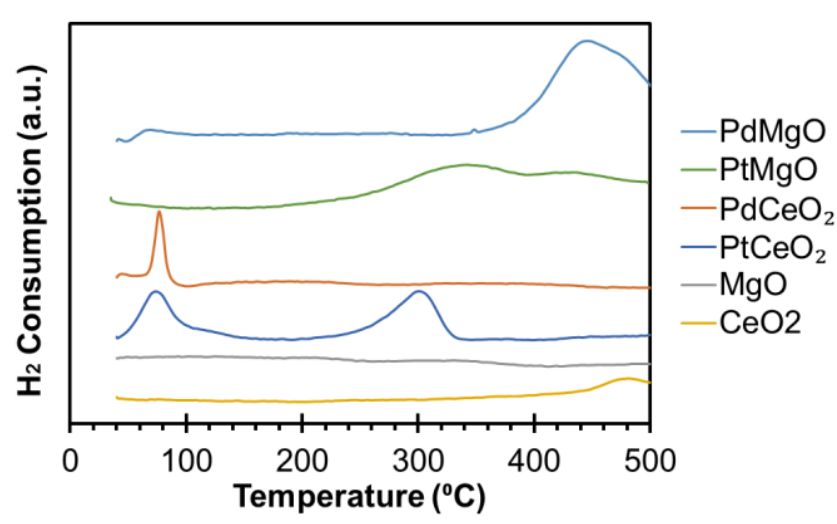

Figure 1. $\mathrm{H}_{2}$-TPR profiles of 1 wt.\% $\mathrm{Pd} / \mathrm{MgO}, \mathrm{Pt} / \mathrm{MgO}, \mathrm{Pd} / \mathrm{CeO}_{2}$, and $\mathrm{Pt} / \mathrm{CeO}_{2}$ as well as the supports $\mathrm{MgO}$ and $\mathrm{CeO}_{2}$

Figure 2 shows low magnification bright field TEM images of the supports $\left(\mathrm{CeO}_{2}\right.$ (a) and $\mathrm{MgO}$ (b)) as well as the four catalysts. The support $\mathrm{CeO}_{2}$ exhibited a regularly arranged morphology with an abundance of cavities. On the other hand, the $\mathrm{MgO}$ support lacked cavities and had a random morphology. This is reflected in the images of the four catalysts as well: $\mathrm{Pt} / \mathrm{CeO}_{2}$ (c), $\mathrm{Pt} / \mathrm{MgO}$ (d), $\mathrm{Pd} / \mathrm{CeO}_{2}$ (e) and $\mathrm{Pd} / \mathrm{MgO}$ (f). Figure 3 shows dark field STEM images for the four catalysts 1 wt. $\% \mathrm{Pt} / \mathrm{CeO}_{2}$ (a), $\mathrm{Pt} / \mathrm{MgO}$ (b), $\mathrm{Pd} / \mathrm{CeO}_{2}$ (c), and $\mathrm{Pd} / \mathrm{MgO}$ (d). The metals deposited on their respective supports were in the nanoparticle range, which agrees with the particle diameter values obtained from $\mathrm{CO}$ pulse chemisorption. The exception to this is $\mathrm{Pt} / \mathrm{MgO}$, as its TEM image suggests a similar particle size to that of $\mathrm{Pd} / \mathrm{MgO}$, in an apparent contradiction to the $\mathrm{CO}$ pulse chemisorption results. This is because chemisorption is a bulk technique, whereas TEM is localized and may not provide images necessarily representative of the entire sample.
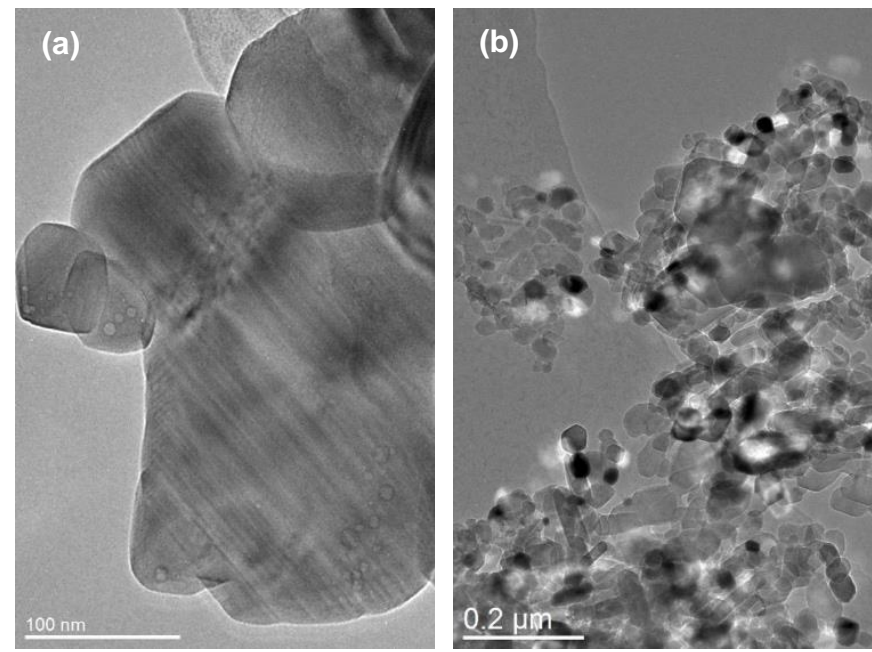

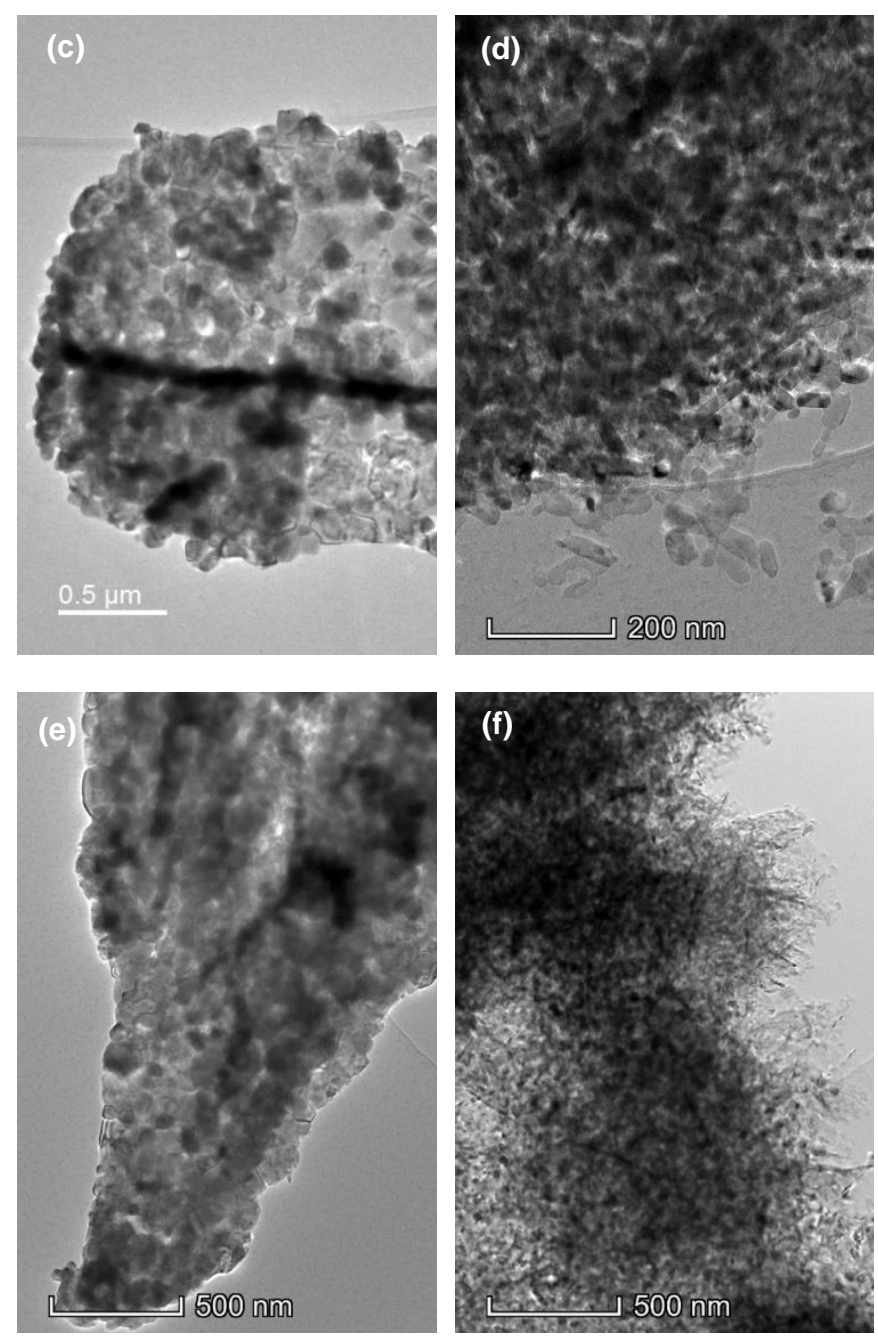

Figure 2. Low magnification bright field TEM images for $\mathrm{CeO}_{2}$ (a), $\mathrm{MgO}$ (b), and 1 wt. \% Pt/CeO 2 (c), $\mathrm{Pt} / \mathrm{MgO}$ (d), $\mathrm{Pd} / \mathrm{CeO}_{2}$ (e), and $\mathrm{Pd} / \mathrm{MgO}$ (f) calcined in static air at $600^{\circ} \mathrm{C}$ for 2 hours
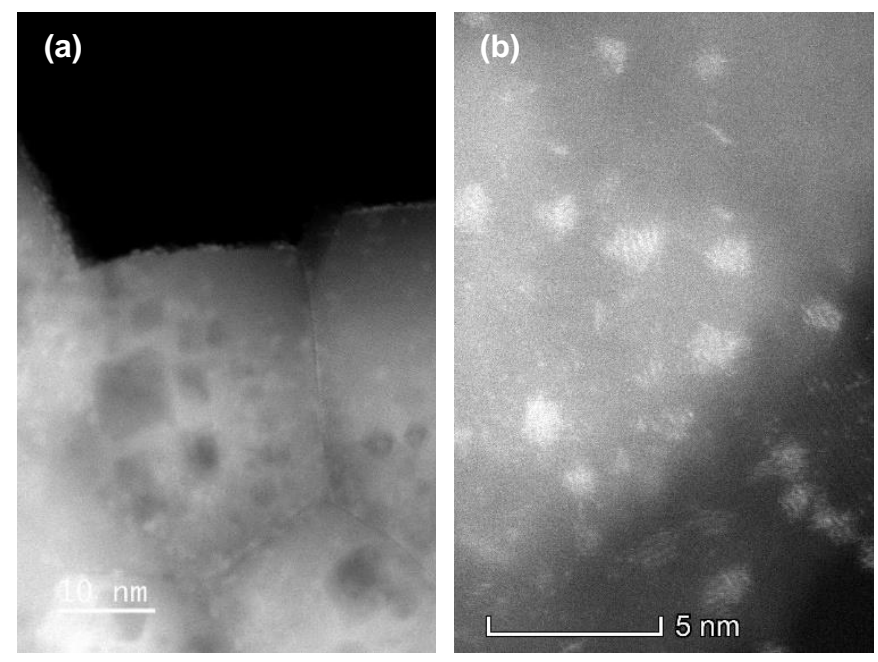
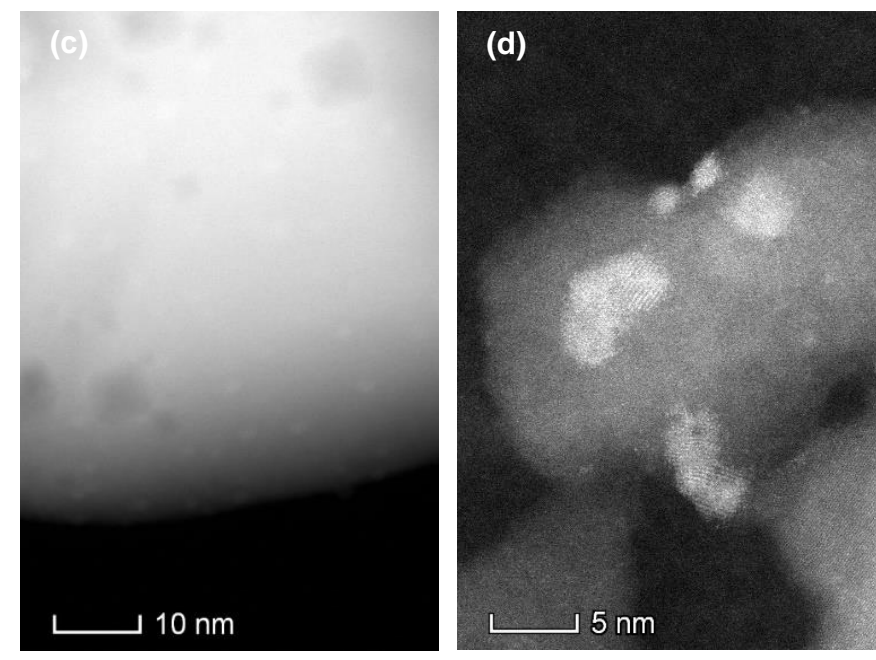

Figure 3. High magnification dark field STEM images for 1 wt. $\% \mathrm{Pt} / \mathrm{CeO}_{2}$ (a), $\mathrm{Pt} / \mathrm{MgO}$ (b), $\mathrm{Pd} / \mathrm{CeO}_{2}$ (c), and $\mathrm{Pd} / \mathrm{MgO}$ (d) calcined in static air at $600^{\circ} \mathrm{C}$ for 2 hours

In addition to imaging the catalysts at low and high magnification, it is necessary to confirm the presence of the metal and the support at the nanoscale as well the absence of any impurities. To achieve that, EELS elemental maps and EDS spectra were obtained. Figure 4 shows EELS elemental maps and EDS spectra of $\mathrm{Pt} / \mathrm{CeO}_{2}$ (a), $\mathrm{Pt} / \mathrm{MgO}$ (b), $\mathrm{Pd} / \mathrm{CeO}_{2}$ (c) and $\mathrm{Pd} / \mathrm{MgO}$ (d). The EELS maps show the distribution of the metals on the supports, and the EDS spectra show peaks of the metals and supports. In the EDS spectra of (a) and (c), the different Ce peaks correspond to different oxidation states of Ce. Overall, the images show that the catalysts were indeed what they were prepared to be and without impurities.

\section{Activity and Catalytic Performance}

The steady-state results of the experiment are shown using three criteria: $\mathrm{NO}$ conversion, $\mathrm{N}_{2}$ selectivity, and $\mathrm{NO}_{2}$ selectivity, which is a measure of the oxidation behavior of the catalysts. Figure 5 shows the $\mathrm{NO}$ conversion $(\mathrm{a}, \mathrm{b})$ and $\mathrm{N}_{2}$ selectivity $(\mathrm{c}, \mathrm{d})$ using $\mathrm{CeO}_{2}$ and $\mathrm{MgO}$ supported catalysts. The $\mathrm{NO}$ conversion and $\mathrm{N}_{2}$ selectivity when only the supports were used are shown on the figure as a baseline. It is evident that the activity stems mostly from the noble metal, as there is a significant difference between the support-only activity and the activity of the support and noble metal combined.

Overall, the $\mathrm{CeO}_{2}$ supported catalysts performed more effectively than their $\mathrm{MgO}$ counterparts in terms of $\mathrm{NO}$ conversion. This can be explained by the results of the $\mathrm{H}_{2}$-TPR experiments shown in Fig. 1, where the $\mathrm{CeO}_{2}$ supported catalysts exhibited strong $\mathrm{H}_{2}$ metal reduction peaks at temperatures below $100^{\circ} \mathrm{C}$, unlike their $\mathrm{MgO}$ counterparts where the reduction peaks were weaker and/or observed at higher temperatures. This indicates that the interactions between the metals and $\mathrm{MgO}$ were stronger than those of the metals with $\mathrm{CeO}_{2}$. 

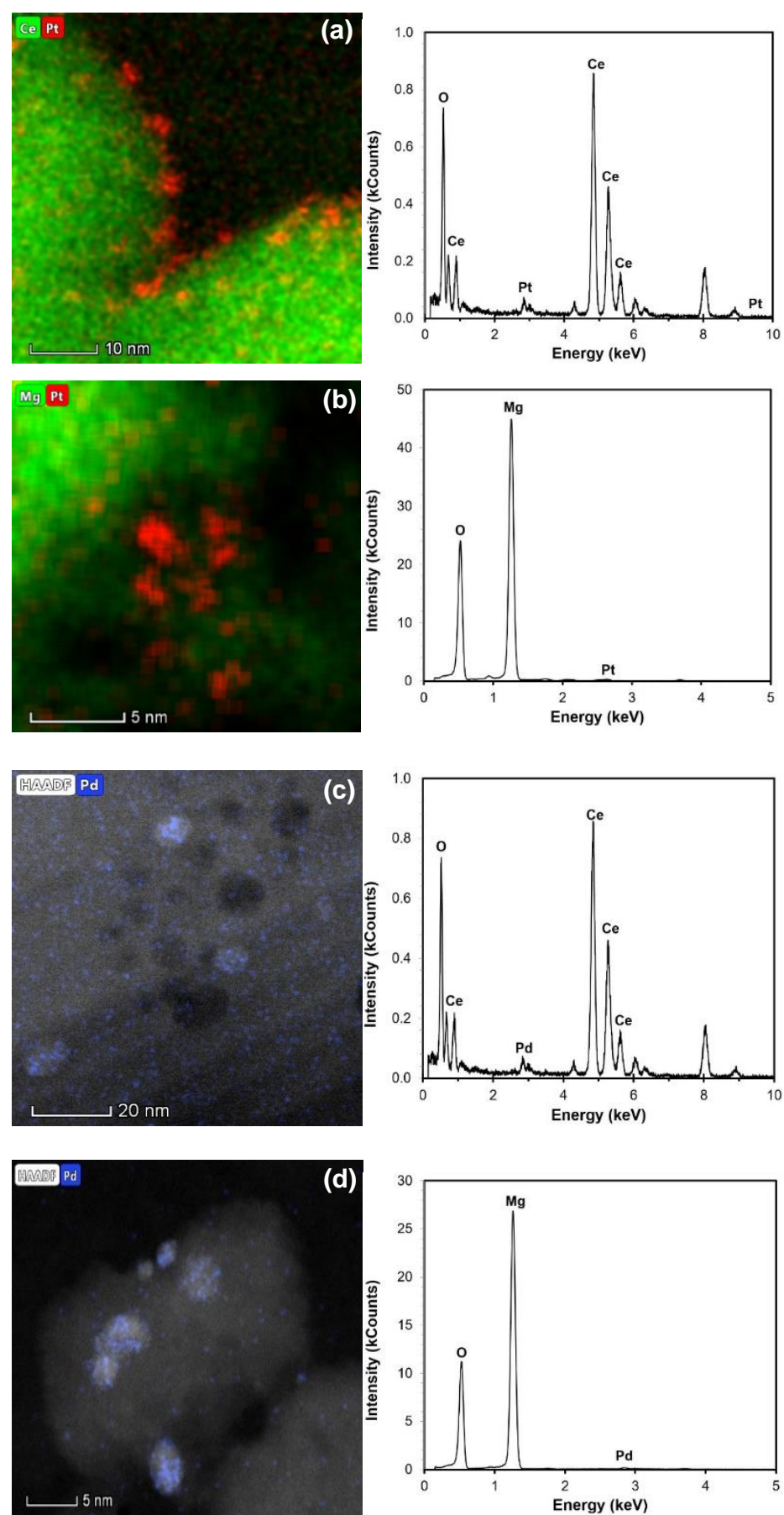

Figure 4. EELS elemental maps and EDS spectra for $\mathrm{Pt} / \mathrm{CeO}_{2}$ (a), $\mathrm{Pt} / \mathrm{MgO}$ (b), $\mathrm{Pd} / \mathrm{CeO}_{2}(\mathrm{c})$ and $\mathrm{Pd} / \mathrm{MgO}$ (d) calcined in static air at $600^{\circ} \mathrm{C}$ for 2 hours

For the $\mathrm{CeO}_{2}$ supported catalysts, $\mathrm{Pt} / \mathrm{CeO}_{2}$ had a consistent conversion of around $60 \%$ across all temperatures, whereas $\mathrm{Pd} / \mathrm{CeO}_{2}$ exhibited a temperature dependence with a maximum conversion of $67 \%$ at $230^{\circ} \mathrm{C}$. For the $\mathrm{MgO}$ supported catalysts, $\mathrm{Pt} / \mathrm{MgO}$ was more active than $\mathrm{Pd} / \mathrm{MgO}$ across all temperatures. In particular, $\mathrm{Pt} / \mathrm{MgO}$ had a maximum conversion of about $50 \%$ at $150^{\circ} \mathrm{C}$, whereas $\mathrm{Pd} / \mathrm{MgO}$ had a maximum conversion of about $15 \%$ in the $230^{\circ} \mathrm{C}-255^{\circ} \mathrm{C}$ region. Interestingly, both $\mathrm{Pd}$ catalysts $\left(\mathrm{Pd} / \mathrm{CeO}_{2}\right.$ and $\left.\mathrm{Pd} / \mathrm{MgO}\right)$ exhibited maximum conversion near $230^{\circ} \mathrm{C}$.
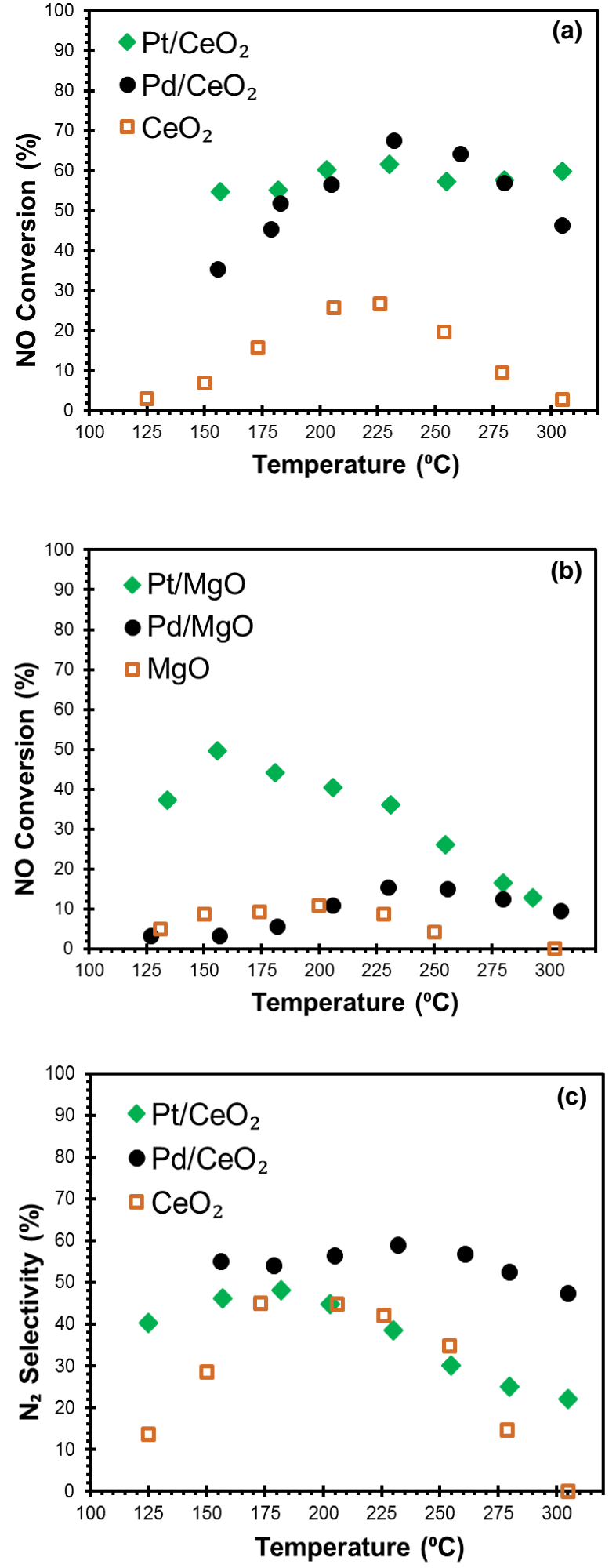


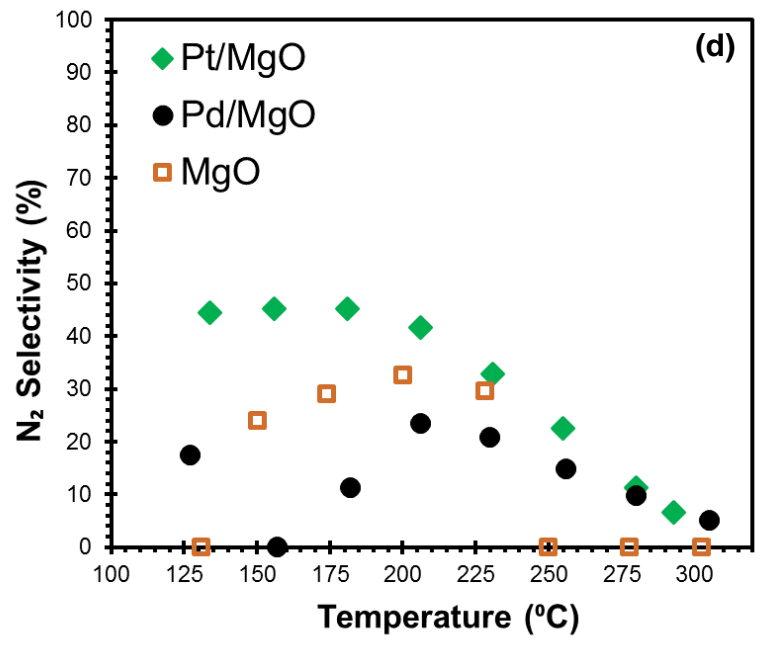

Figure 5. $\mathrm{NO}$ conversion for $\mathrm{CeO}_{2}$ (a) and $\mathrm{MgO}$ (b) supported catalysts, and $\mathrm{N}_{2}$ selectivity for $\mathrm{CeO}_{2}$ (c) and $\mathrm{MgO}$ (d) supported catalysts

Throughout the entire temperature range considered, the $\mathrm{CeO}_{2}$ catalysts performed more effectively than their $\mathrm{MgO}$ counterparts in terms of $\mathrm{N}_{2}$ selectivity. The difference in $\mathrm{N}_{2}$ selectivity between the $\mathrm{CeO}_{2}$ and $\mathrm{MgO}$ catalysts can be explained by the intermediates which the supports $\mathrm{CeO}_{2}$ and $\mathrm{MgO}$ promote. Costa et al. [7] studied the catalyst $\mathrm{Pt} / 50 \mathrm{MgO}-50 \mathrm{CeO}_{2}$ and provided kinetic insights into the intermediate species formed under $\mathrm{NO} \mathrm{H}_{2}$-SCR reaction conditions. They found that active bidentate $\mathrm{NO}^{-3}$ formed on $\mathrm{MgO}$, whereas on $\mathrm{CeO}_{2}, \mathrm{NO}^{+}$coadsorbed with $\mathrm{NO}^{-3}$ and reacted together to strongly promote the formation of $\mathrm{N}_{2}$ and $\mathrm{H}_{2} \mathrm{O}$.

Among the $\mathrm{CeO}_{2}$ catalysts, $\mathrm{Pd} / \mathrm{CeO}_{2}$ was more selective to $\mathrm{N}_{2}$ than was $\mathrm{Pt} / \mathrm{CeO}_{2}$ across all temperatures, as shown in Fig. 5 (c). The $\mathrm{N}_{2}$ selectivity for $\mathrm{Pd} / \mathrm{CeO}_{2}$ was in the $50-60 \%$ range with small fluctuations across the temperature window studied, whereas $\mathrm{Pt} / \mathrm{CeO}_{2}$ exhibited a maximum $\mathrm{N}_{2}$ selectivity at $180^{\circ} \mathrm{C}$ with low selectivity at both ends of the temperature range. The decline in $\mathrm{N}_{2}$ selectivity of $\mathrm{Pt} / \mathrm{CeO}_{2}$ at higher temperatures was due to forming $\mathrm{NO}_{2}$, which is discussed in the following paragraph. Note, however, that there was not much difference in the $\mathrm{N}_{2}$ selectivity of $\mathrm{Pt} / \mathrm{CeO}_{2}$ and $\mathrm{CeO}_{2}$ (i.e. the support alone) in the range of $175^{\circ} \mathrm{C}-250^{\circ} \mathrm{C} . \mathrm{Pt} / \mathrm{MgO}$ was more selective to $\mathrm{N}_{2}$ than was $\mathrm{Pd} / \mathrm{MgO}$ for temperatures up to $275^{\circ} \mathrm{C}$, at which point the two catalysts started exhibiting similar behavior as shown in Fig. 5 (d). Pt/MgO was more selective to $\mathrm{N}_{2}$ with a selectivity of $45 \%$ at $175^{\circ} \mathrm{C}$, whereas the maximum $\mathrm{N}_{2}$ selectivity of $\mathrm{Pd} / \mathrm{MgO}$ was $25 \%$ at $210^{\circ} \mathrm{C}$.

Figure 6 shows the $\mathrm{NO}_{2}$ selectivity of $\mathrm{Pt} / \mathrm{CeO}_{2}$; the other three catalysts had $\mathrm{NO}_{2}$ selectivity below the detection limit. $\mathrm{Pt} / \mathrm{CeO}_{2}$ started exhibiting an oxidation behavior at $150^{\circ} \mathrm{C}$ in a linear fashion through the upper limit of the temperature range. This oxidation behavior can be attributed to the oxygen-rich environment present on the $\mathrm{CeO}_{2}$ support. The existence of such an environment is an inherent feature of $\mathrm{CeO}_{2}$, as can be seen in the $\mathrm{CeO}_{2} \mathrm{H}_{2}$-TPR results in Fig. 1. The interaction between $\mathrm{Pt}$ and $\mathrm{CeO}_{2}$ shifted the surface oxygen peak from $480^{\circ} \mathrm{C}$ to $300^{\circ} \mathrm{C}$, which facilitated oxidation at lower temperatures, as observed in Fig. 6. On the other hand, the interaction between Pd and $\mathrm{CeO}_{2}$ reduced the support oxidation behavior, which translated to a shift in the surface oxygen peak to higher temperatures.

The oxidation behavior of Pt-based catalysts has been observed in HCSCR studies [20]. Additionally, Ji et al. mechanistically studied the oxidation behavior of $\mathrm{Pt} / \mathrm{CeO}_{2}$ and reported that it had a significant $\mathrm{NO}$ oxidation capacity. They also added that $\mathrm{NO}$ could be oxidized on unprompted ceria; given that and the oxidation capacity of $\mathrm{Pt} / \mathrm{CeO}_{2}$, the authors concluded that it was highly likely for NO to be oxidized through an oxygen spillover mechanism, where oxygen migrates from Pt to the support for the oxidation of NO [21]. This speaks for the important role of adsorbed oxygen atoms on the activity and selectivity of these systems.

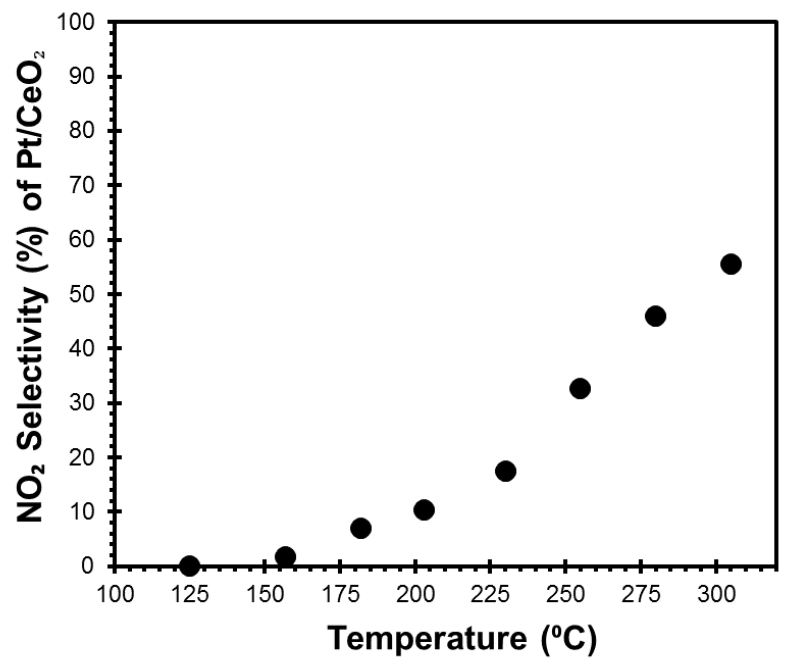

Figure 6. $\mathrm{NO}_{2}$ selectivity of $\mathrm{Pt} / \mathrm{CeO}_{2}$

The current study partially mimics operating conditions downstream of lean-burn engines. The oxygen content used in the current study was $10 \%$, which is much higher than previously reported in $\mathrm{H}_{2}-\mathrm{SCR}$ studies, where the oxygen content is typically $5 \%$. Specifically, the $10 \%$ oxygen content imitates lean-burn conditions reported in engine studies [22]. The high oxygen content was expected to affect the selectivity drastically, as it promotes the production of $\mathrm{H}_{2} \mathrm{O}$ and negatively influences the production of $\mathrm{N}_{2}$. However, despite the effects that stem from the oxygen-rich environment, the activity and selectivity results show great promise for $\mathrm{H}_{2}-\mathrm{SCR}$ in lean-burn conditions. In addition to highlighting the many challenges that $\mathrm{H}_{2}-$ SCR still has to overcome, such as providing $\mathrm{H}_{2}$ on-board a vehicle, our results demonstrate that it is possible to treat $\mathrm{NO}$ emissions at a lower temperature window relevant to engine cold start, unlike $\mathrm{NH}_{3}-$ $\mathrm{SCR}$, where low temperature activity is a challenge.

\section{Conclusions}

Utilizing $\mathrm{H}_{2}$ in the catalytic treatment of $\mathrm{NO}$ emissions under lean-burn conditions was studied over a series of Pt- and Pd-containing catalysts supported on $\mathrm{CeO}_{2}$ and $\mathrm{MgO}$. Compared to $\mathrm{MgO}$ for effective $\mathrm{H}_{2}-$ $\mathrm{SCR}, \mathrm{CeO}_{2}$ provided a better support for $\mathrm{Pt}$ and $\mathrm{Pd}$ metals, as higher dispersion was achieved and the metal $\mathrm{H}_{2}$ reduction was more pronounced and at lower temperatures. Among the two $\mathrm{CeO}_{2}$ catalysts tested, 1 wt. $\% \mathrm{Pd} / \mathrm{CeO}_{2}$ showed the best performance with a conversion of $67 \%$ and $\mathrm{N}_{2}$ selectivity of about $70 \%$ at $230^{\circ} \mathrm{C}$. Although $\mathrm{Pt} / \mathrm{CeO}_{2} \mathrm{NO}$ conversion competed with that of $\mathrm{Pd} / \mathrm{CeO}_{2}$ over the temperature range studied, $\mathrm{Pt} / \mathrm{CeO}_{2}$ promoted the activity of $\mathrm{CeO}_{2}$ surface oxygen, resulting in an oxidation behavior and rendering $\mathrm{Pt} / \mathrm{CeO}_{2}$ ineffective for this application.

Future work includes investigating the effects of adding $\mathrm{H}_{2} \mathrm{O}$ as well as other components, such as $\mathrm{CO}, \mathrm{CO}_{2}$ and $\mathrm{SO}_{2}$, on the catalyst activity. Additionally, further characterizing the surface via techniques such as X-Ray Diffraction (XRD) will enable examining the

Page 7 of 9 
crystallinity of the surface and the effects thereof. Lastly, given that the Pt loading was consistently lower than that of $\mathrm{Pd}$, the preparation method and the choice of precursor will be further investigated to achieve the desired $1 \mathrm{wt} . \%$ loading.

The activity and selectivity results from the present study, where the oxygen content is higher than previously reported in the literature, sheds light on the possibility of treating NO emissions at a low operating temperature window using $\mathrm{H}_{2}$-SCR, unlike in $\mathrm{NH}_{3}-\mathrm{SCR}$ where low temperature activity is a challenge. This is of great relevance to engine cold start conditions and may well be the distinguishing factor behind implementing $\mathrm{H}_{2}-\mathrm{SCR}$ as an environmentally benign after-treatment technology in the future.

\section{References}

1. Agency for Natural Resources and Energy, "Key World Energy statistics," IEA Int. Energy Agency, 2017.

2. Energy Information Administration (EIA), "Transportation Sector Energy Consumption," Int. Energy Outlook 2016, vol. 2016, pp. 127-137, 2016.

3. Umicore, "Three Way Catalyst (TWC)." [Online]. Available: http://ac.umicore.com/en/technologies/three-waycatalyst/.

4. M. JabŁońska, A. E. Palomares Gimeno, A. Wegrzyn, and L. Chmielarz, "A short review about NOx storage/reduction catalysts based on metal oxides and hydrotalcite-type anionic clays," Acta Geodyn. Geomater., vol. 11, no. 2, pp. 175-186, 2014.

5. "WHAT IS A DIESEL OXIDATION CATALYST?" [Online]. Available: https://www.nettinc.com/information/emissions-faq/what-isa-diesel-oxidation-catalyst.

6. G. Qi, L. Wang, and R. T. Yang, "Urea-SCR Technology for deNOx After Treatment of Diesel Exhausts," no. x, 2014.

7. C. N. Costa and A. M. Efstathiou, "Mechanistic aspects of the $\mathrm{H} 2-\mathrm{SCR}$ of $\mathrm{NO}$ on a Novel $\mathrm{Pt} / \mathrm{MgO}-\mathrm{CeO} 2$ catalyst," $J$. Phys. Chem. C, vol. 111, no. 7, pp. 3010-3020, 2007.

8. Z. Liu et al., "Selective catalytic reduction of NOxwith H2over WO3promoted Pt/TiO2catalyst," Appl. Catal. B Environ., vol. 188, no. x, pp. 189-197, 2016.

9. C. Xu, W. Sun, L. Cao, T. Li, X. Cai, and J. Yang, "Highly efficient Pd-doped aluminate spinel catalysts with different divalent cations for the selective catalytic reduction of NO with H2at low temperature," Chem. Eng. J., vol. 308, pp. 980-987, 2017.

10. K. Duan, Z. Liu, J. Li, L. Yuan, H. Hu, and S. I. Woo, "Novel Pd-Au/TiO2catalyst for the selective catalytic reduction of NOxby H2," Catal. Commun., vol. 57, pp. 1922,2014

11. J. Li, G. Wu, N. Guan, and L. Li, "NO selective reduction by hydrogen over bimetallic Pd-Ir/TiO2catalyst," Catal. Commun., vol. 24, pp. 38-43, 2012.

12. C. N. Costa, P. G. Savva, J. L. G. Fierro, and A. M. Efstathiou, "Industrial H2-SCR of $\mathrm{NO}$ on a novel Pt/MgOCeO2catalyst," Appl. Catal. B Environ., vol. 75, no. 3-4, pp. 147-156, 2007.

13. C. N. Costa and A. M. Efstathiou, "Pt/Mg-Ce-O catalyst for NO/H2/O2 lean de-No x reaction," Environ. Chem. Lett., vol. 2, no. 2, 2004.

14. I. Contreras-andrade and A. Va, "Influence of the Synthesis Method on the Catalytic Behavior of Pt and PtSn / Al 2 O 3 Reforming Catalyst," no. 14, pp. 3835-3841, 2009.

15. P. Canton, G. Fagherazzi, M. Battagliarin, F. Menegazzo, F. Pinna, and N. Pernicone, "Pd / CO Average Chemisorption Stoichiometry in Highly Dispersed Supported Pd / $\gamma-\mathrm{Al} 2 \mathrm{O}$ 3 Catalysts," no. 8, pp. 6530-6535, 2002.

16. B. Chen et al., "Catalyst for Enhanced Toluene Catalytic Oxidation," 2018

17. M. L. Â, Z. Hou, X. Yuan, and X. Zheng, "Characterization study of $\mathrm{CeO} 2$ supported Pd catalyst for low-temperature carbon monoxide oxidation," vol. 50, pp. 205-209, 1998.

18. A. Ben1, V. Borau, R. Ruiz, and F. Urbano, "Study of MgO and Pt / MgO Systems by XRD, TPR, and $1 \mathrm{H}$ MAS NMR," no. 26, pp. 1192-1197, 1999.

19. P. Claus, H. Berndt, C. Mohr, E. Shin, and M. A. Keane, "Pd / $\mathrm{MgO}$ : Catalyst Characterization and Phenol Hydrogenation Activity," vol. 97, pp. 88-97, 2000.

22. F. Jacquot, J. Brilhac, L. Gestion, and U. D. H. Alsace, "Soot Oxidation by O 2 and / or NO 2 in the Presence of Catalysts Under Lean-Burn and Rich Atmospheres Reprinted From : Emissions Technologies," no. 2, 2019.

20. K. Shimizu and A. Satsuma, "Selective catalytic reduction of NO over supported silver catalysts-practical and mechanistic aspects," Phys. Chem. Chem. Phys., 2006, 8, 2677-269.

21. Y. Ji, T. Toops, U. Graham, G. Jacobs, and M. Crocker, "A kinetic and DRIFTS study of supported Pt catalysts for NO oxidation," Catalysis Letters Vol. 110, Nos. 1-2, August 2006.

22. F. Jacquot, J. Brilhac, L. Gestion, and U. D. H. Alsace, "Soot Oxidation by O 2 and / or NO 2 in the Presence of Catalysts Under Lean-Burn and Rich Atmospheres Reprinted From : Emissions Technologies,” no. 2, 2019.

\section{Contact Information}

Nawaf M. Alghamdi

Clean Combustion Research Center, King Abdullah University of Science and Technology (KAUST)

Email: nawaf.alghamdi@kaust.edu.sa

Christos Kalamaras, PhD

Fuel Technology, Saudi Aramco Research and Development Center Email: christos.kalamaras@aramco.com

\section{Acknowledgments}

The authors would like to acknowledge the funds allocated to this study by King Abdullah University of Science and Technology (KAUST), the Fuel Technology Division in the Research and Development Center of Saudi Aramco, and King Abdulaziz City for Science and Technology (KACST). Our thanks go to Rachid Sougrat and Daliang Zhang from the KAUST Imaging and Characterization Core Lab as well as Omar El Tall from the KAUST Analytical Core Lab for their tremendous help and guidance. 


\section{Appendix}

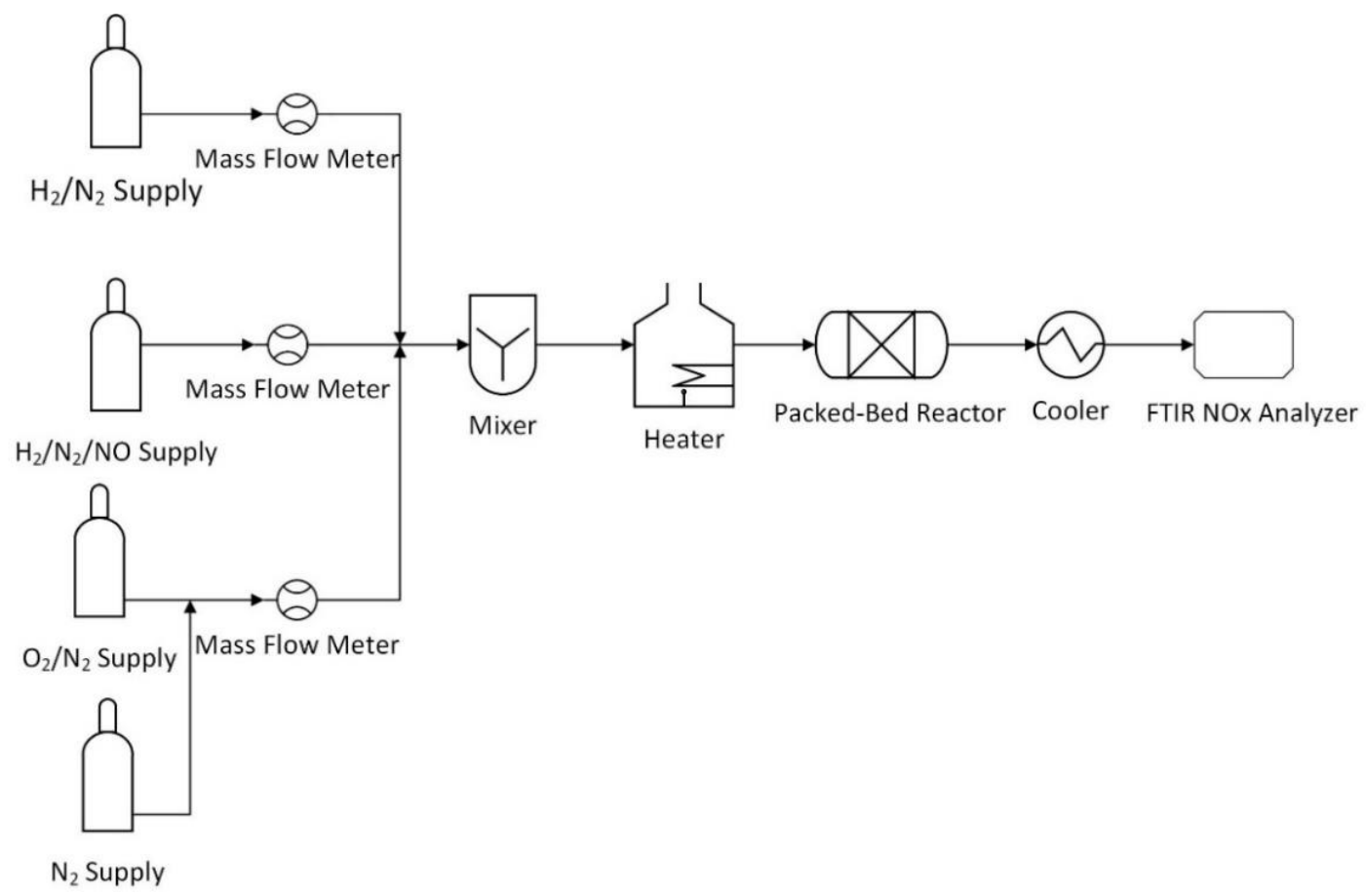

Figure S7. Schematic diagram of the experimental setup

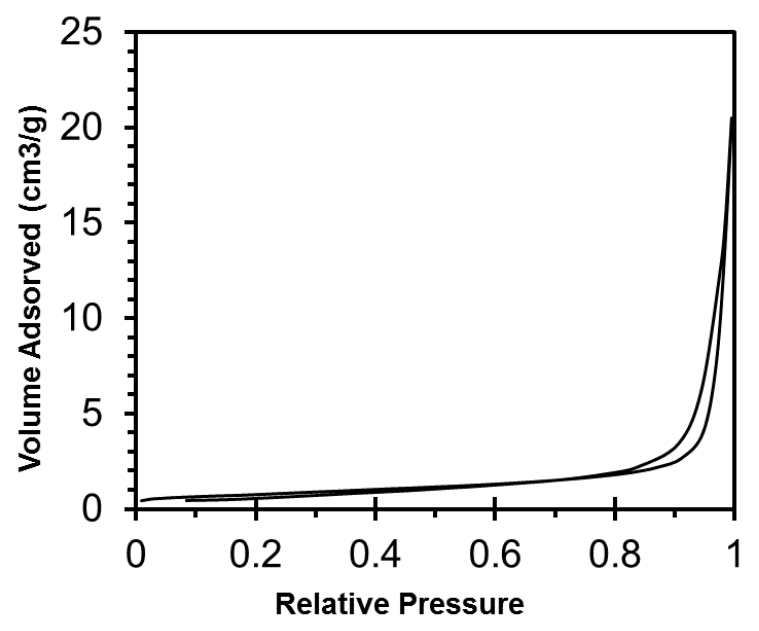

Figure S8. Adsorption isotherm of $\mathrm{CeO}_{2}$

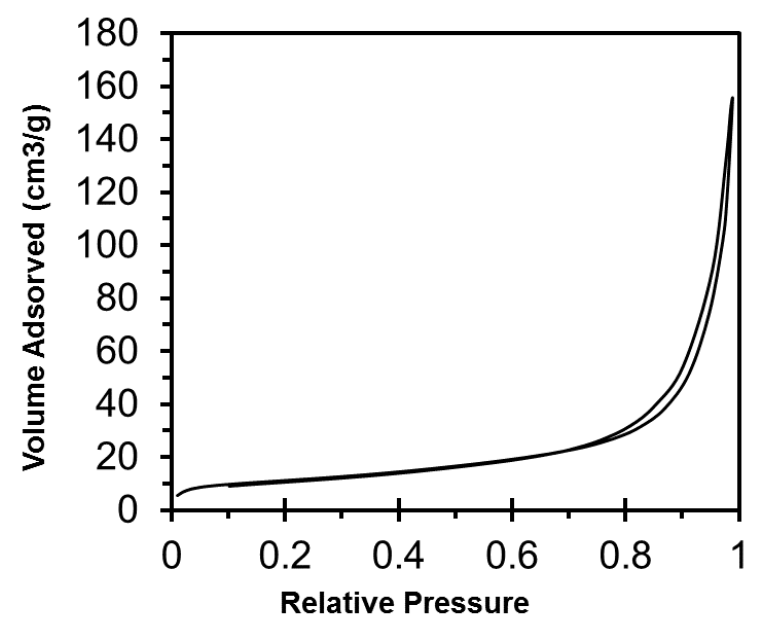

Figure S9. Adsorption isotherm of $\mathrm{MgO}$ 